\title{
The vernacular house between the Cávado and the Ave, Portugal
}

\author{
C.E. Barroso, D.V. Oliveira, L.F. Ramos \& P.B. Lourenço \\ ISISE, Universidade do Minho, Guimarães, Portugal
}

\begin{abstract}
With acknowledged authenticity and cultural heritage value, rural vernacular construction of Entre-Douro-e-Minho represents the results of the centuries-old relation between men and available natural resources. Abandoned or victim of armful interventions, this unique heritage acquired economical value by the growing interest on rural environment and life. It represents a mean to economical and social boosting of these depressed areas, but at the same time exposing them to the threatening lack of knowledge and property speculation. In order to protect and prevent future damages to this fragile heritage, it's fundamental the study and identification of its identity and technical-constructive key features. This paper presents the results of a fieldwork study performed between the Cávado and Ave rivers, which aimed to identify morfo-typologies, materials and construction techniques of the existent schist heritage. The data collected aims to contribute to its preservation and to assist technicians in future rehabilitation projects in the area.
\end{abstract}

\section{STUDY AREA CHARATERIZATION}

The selected territory to carry out the study, see Figure 1, corresponds to the limits of Barqueiros, a village of $8 \mathrm{~km}^{2}$ of the Municipality of Barcelos near the Cávado river, located in the coastal strip of the Entre-Douro-e-Minho (Ribeiro, 1945).

The first human settlements in the area occurred during roman occupation, near the valleys located to the west, and the existent road network, and were a consequence of territorial mining, river and agricultural exploration (Araújo, 2001). Agricultural exploration endured in time, and in the 18th century it originated new independent settlements in the north and northeast areas. In this period,

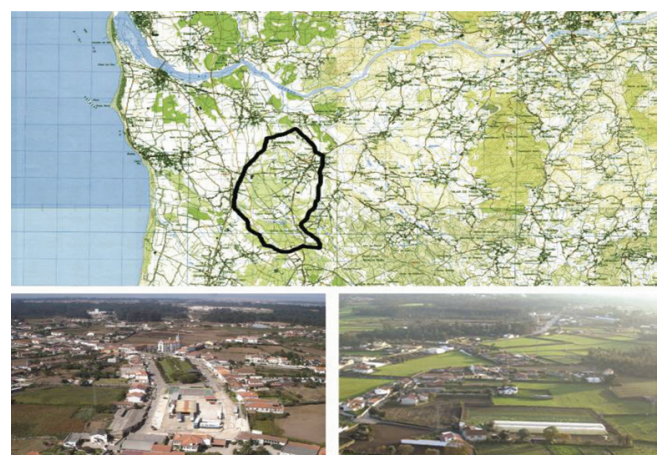

Figure 1. Study area's limits on Portuguese military chart $\left(41^{\circ} 29^{\prime} 6.46^{\prime \prime} \mathrm{N}, 8^{\circ} 43^{\prime} 43.43\right.$ "W). Northeast views. (Credits: C.E. Barroso et al.). local rural society was organized between landowners and workers (Basto \& Barros, 1943), territory between production areas in the valleys, and production forest in infertile areas, and construction between dwelling and production buildings. In the mid-18th century, with the development of the Marian devotion at the Royal Sanctuary of N. S. ${ }^{a}$ of Necessidades and the Sanctuary of N. S. ${ }^{a}$ of Amparo, new settlements shaped with urban principles and public spaces emerged in the northeast and northwest areas, supported a strong commercial and industrial sectors, and led to the establishment bourgeois social classes and the "brasileiro" emigrant investment (Monteiro, 2000).

\section{FIELDWORK}

The fieldwork was carried out by on-site observation and data collecting through geometrical and photographic surveys, interviews and the support of information from several rural studies and researches performed until the 1960s (Barroso, 2012).

\subsection{Agricultural based buildings}

These buildings were strongly characterized by their high optimization to farming demands (Oliveira \& Galhano, 1992), and were the result of a secular research. They can be described as family productive structures, locally named casas de lavoura (Fonseca, 1987), and corresponded to farming complexes composed by a dwelling, 
agricultural premises and outbuildings, all organized along the perimeter of an external enclosed area, separated from the farm and the road. Morfo-typologically, these buildings can be labeled as Basic and Composed Elementary Farmhouses, rented or property of rural workers or small farmers, Block and Courtyard Farmhouses, properties of big farmers (Oliveira \& Galhano, 1992).

These were widespread, austere aspect complexes, aesthetically and constructively improved only in the dwelling's volume, and composed of one floor volume with $2.5 \mathrm{~m}$ height on average, having a second floor for dwellings and special agricultural premises in larger complexes. Of overall horizontality, these were parallelepiped and regular proportion buildings, aggregated in $\mathrm{L}$ compositions.

As seen in Figure 2, complexes were constructed at the farm's limits and organized from the road.

The dwelling was placed with one façade facing the road or over corners, either using the lateral complex's wall, with one or two usable fronts, or in a central position, gaining three to four usable fronts.

The south orientation was predominant, allowing porches in dwellings for insulation control and cereal drying. Accesses from the road or farm to the enclosed complex were limited to vehicle portals, generally located under the dwelling or porch, and from it to the individual buildings.

Internal connections between buildings were limited or non-existent. Habitability conditions were very poor, either by general low construction quality, or the absence of basic infrastructure and toilets, only introduced in mid-19th century, or cattle smells from premises, under or next to the dwellings. In spite of strong interior ventilation, moister was always present, especially in one floor buildings with compact soil pavements. In smaller houses, individual spaces were non-existent, and family life occurred in the living room (Basto \& Barros, 1943).

The kitchen, along with cattle proximity, was the only internal heat source, and in smaller dwellings it was a part of the living room. It was composed of the granite stone slab of the fireplace and the oven, and, when located at ground floor level, it

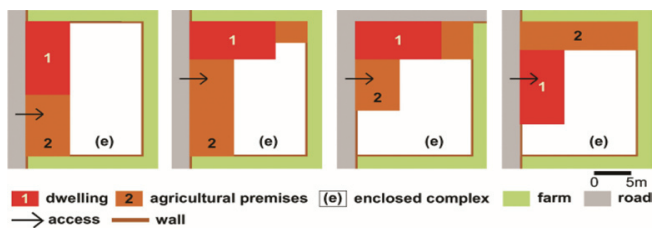

Figure 2. Agricultural complexes' site occupation schemes. (Credits: C.E. Barroso et al.). had a compact soil pavement. Until the introduction of the chimney in the 19th century (Oliveira \& Galhano, 1992), the deficient smoke extraction by roof or wall openings was responsible for the constant presence of smoke and soot inside the dwelling. As dwellings got larger, the kitchen became an independent compartment or building, allowing a more ceremonial living room (Oliveira \& Galhano, 1992).

As seen in Figure 3, Elementary Farmhouses were small, a one floor building, with simplified partitioning and constructed in small plots of land. Basic models were of low construction quality buildings, divided by a masonry wall in a single dwelling compartment, sometimes divided by timber frame walls into living room and bedroom, and a small agricultural compartment to support survival agriculture.

Construction areas were of about $20 \mathrm{~m}^{2}$ to $40 \mathrm{~m}^{2}$, with $2.5 \mathrm{~m}$ height, with gable roofs, no ceilings, with openings in the plot façade, complemented with small ventilation openings on the opposite wall.

Composed models presented better construction quality and larger areas that allowed more openings and independent compartments for bedrooms and a kitchen with independent access from the complex. In these larger models, the agricultural complex takes shape with specialized premises, occupying around $50 \%$ of constructed area.

Block Farmhouses, locally named casas torre, see Figure 4, were characterized by the vertical presence of a two-floors building composed by the dwelling, now in the upper floor, and storage and cattle premises in the ground floor, placing in the same horizontal area two different functions (Oliveira \& Galhano, 1992). Thus, the dwelling had better moister protection, it gained the warmth produced by the cattle below and visual domain over the farm.

Overall construction quality was improved and dwelling's area was larger with widths of around $6 \mathrm{~m}$, allowing more complex internal organizations

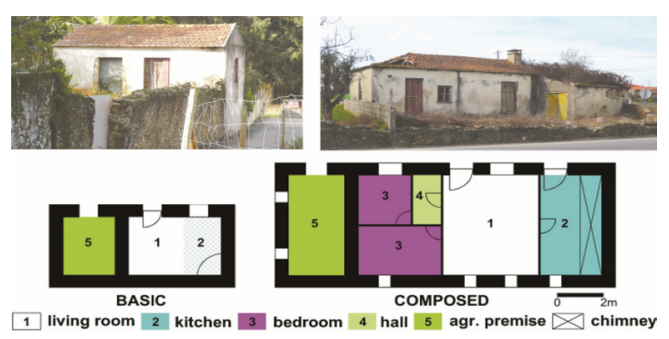

Figure 3. Examples of basic and composed elementary farmhouses. Schematic representations of common dwellings' layout. (Credits: C.E. Barroso et al.). 


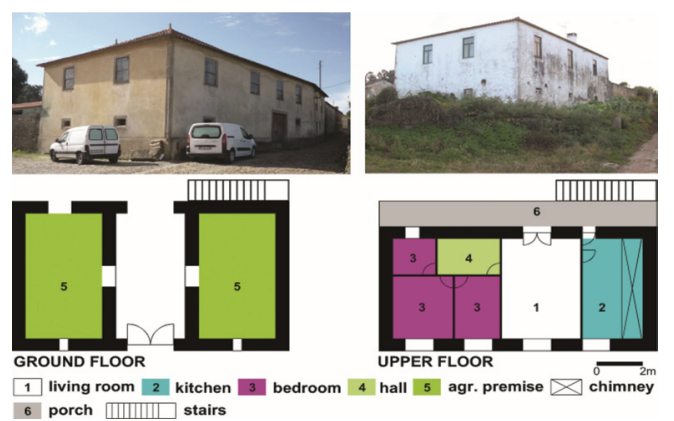

Figure 4. Examples of block farmhouse. Schematic representation of most common dwellings' layout. (Credits: C.E. Barroso et al.).

that included the kitchen also in the upper floor. An exterior granite stair, parallel or perpendicular to the rear façade, connected the external enclosed area to the upper floor porch or entrance of the dwelling.

The agricultural complex was organized in an L configuration, occupying over $50 \%$ of the constructed area, and included specialized agricultural premises like the varandão, a two-floor outbuilding independent or next to the main building, for grain and cereal storage and drying, the winery or the $30 \mathrm{~m} 2$ granite threshing floor or eira.

The Courtyard Farmhouses, very common in isolated or larger complexes, were composed by an elementary composed or block dwelling, and as seen in Figure 5, inserted in an agricultural complex organized in one or multiple $\mathrm{U}, \mathrm{O}$, or opposite sides of the courtyard complex. Their agricultural premises and outbuildings had high independence and very specialized functions like the workers' accommodations, production kitchens, water and windmills, etc.

\subsection{Street agricultural based buildings}

By the mid-18th century, with the growing influence of the new religious Marian cults, and its growing number of pilgrims, local agricultural based buildings evolved to accommodate the new emerging commercial and services dynamics, and to better correspond to the more urban aesthetic taste of the new established social classes. Roads in the proximities of the Marian sanctuaries, and the new Royal Road 30, were transformed into streets that became a defining element in these new morfo-typologies, making the farmhouse less defensive and more permeable in relation to the public space.

Morfo-typologically speaking, these buildings maintained the previous models' labels as Ele-
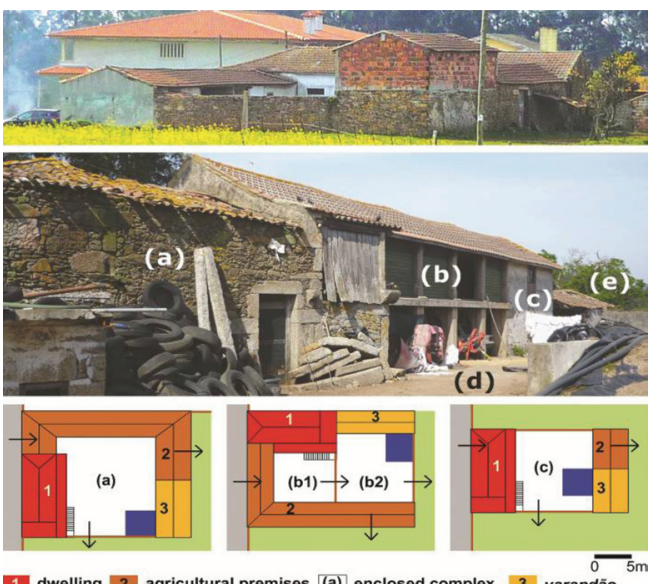

1 dwelling 2 agricultural premises (a) enclosed complex 3 varandä

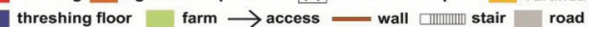

Figure 5. Example of a courtyard farmhouse. Example of agricultural outbuilding: (a) shed; (b) varandão (c) workers' accommodations; (d) eira; (f) watermill. Schematic representations of courtyard complexes configurations: (a) U; (b1; b2) multi courtyard; (c) opposite sides. (Credits: C.E. Barroso et al.).

mentary, Block and Courtyard, adding to each the Adapted and Mixed Street Farmhouses labels. The progressive increase of influence of commerce over agriculture led to the development of models with a small or residual presence of agricultural premises, like the Row Street Houses and the Bourgeois or "Brasileiro" Street Houses (Barroso, 2012).

Overall and aesthetically, these buildings were characterized by ground floor windows and direct doors to the street, and façade stairs and balconies in two floors buildings, see Figure 6.

Overall construction's quality is substantially increased from the mid-19th century, by the introduction of mechanical prepared materials (Teixeira, 2004), such as openings and balcony standard curbs, decorative stone worked masonry, improved frames and Marselha roof tiles. Except for agricultural premises and kitchens that kept compact soil pavements, raised and ventilated wooden pavements became frequent. Internal functional independence between different buildings' uses and areas was maintained. Commercial spaces occupied the front part or the entire ground floor, sharing it with agricultural premises concentrated at the rear. They had independent street access but limit access to the rest of the building and to the enclosed complex, occupied with agricultural premises and outbuildings.

The dwelling's space became more complex with the increase in compartments number, 

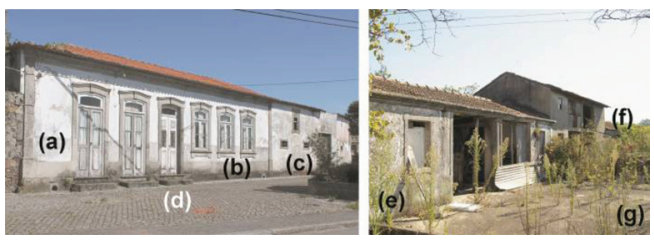

Figure 6. Example of a courtyard street farmhouse with a mixed composed elementary dwelling. Façade: (a) commercial space; (b) dwelling; (c) agricultural premises; (d) access to the dwelling. Courtyard: (e) porch; (f) varandão, (g) eira. (Credits: C.E. Barroso et al.).

functions and connection spaces. On one floor buildings, dwellings shared the building with the other two functions. On two floors buildings, it occupied the upper floor and spread to the ground floor by an entrance hall, that connected the dwelling by timber staircases, to the street and to the remaining internal and external areas.

Overall habitability improved considerably by the influence of the first sanitation regulations in the 19th century. Improvements occurred in ventilation conditions, by the increase of the average internal heights to $3 \mathrm{~m}$; in lighting, by the increase in windows' size from a square of $1.2 \mathrm{~m}$ to rectangular $1.2 \mathrm{~m} \times 1.5 \mathrm{~m}$ proportion; and in comfort, by the generalization of the internal or external toilets.

Adapted Street Farmhouses, see Figure 7, were the result of the adaptation of existing farmhouses to accommodate commercial premises. A process of internal functional reorganization was performed, and elements like ground floor doors and windows, even façade stairs and entire new sectors, were constructed, resulting frequently in buildings' aesthetic incoherence. Mixed Street Farmhouses were overall aesthetic and functional coherent buildings, built from scratch to incorporate all three functions.

As seen in Figure 8, Row Street Houses were two-floors buildings, frequently with an added third floor. They were built in $6 \mathrm{~m}$ wide modules, with two openings per floor, and an average $10 \mathrm{~m}$ depth, occupying the entire plot of land, with gable roofs and sharing structural partition walls. Entrance hall, commercial and small agricultural premises occupied the ground floor, and the dwelling the remaining ones. Toilets were very frequent in these buildings.

Bourgeois and "Brasileiro" Street Houses, see Figure 9, were two or three floors buildings, with strong urban influence, superior construction quality, larger constructed areas, heights of average $4 \mathrm{~m}$ by floor, good habitability conditions, and aesthetic diversity.

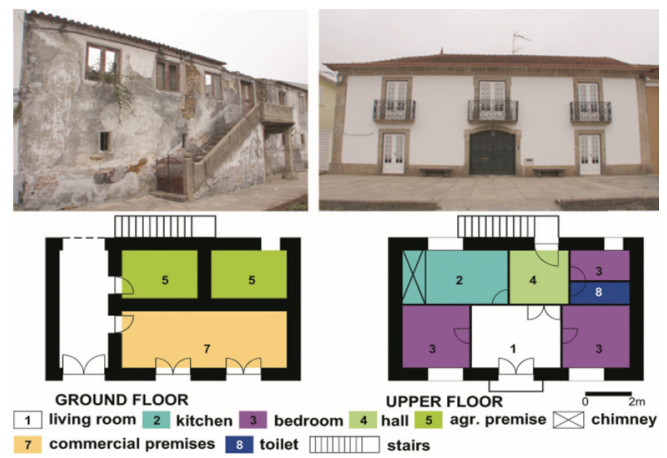

Figure 7. Examples of adapted and mixed farmhouses. Schematic representation of most common dwellings' layout. (Credits: C.E. Barroso et al.).

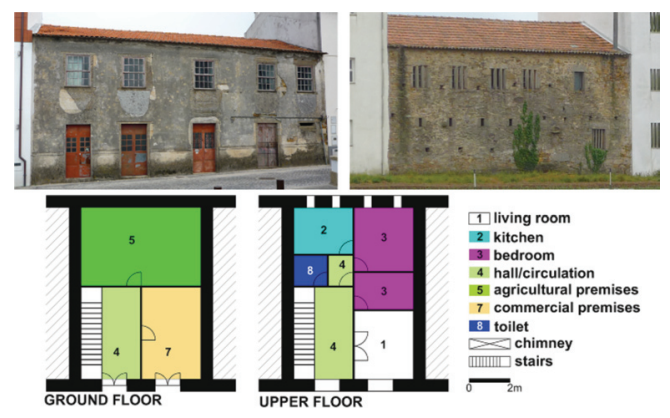

Figure 8. Example of a row house. Schematic representations of most common dwellings' layout. (Credits: C.E. Barroso et al.).
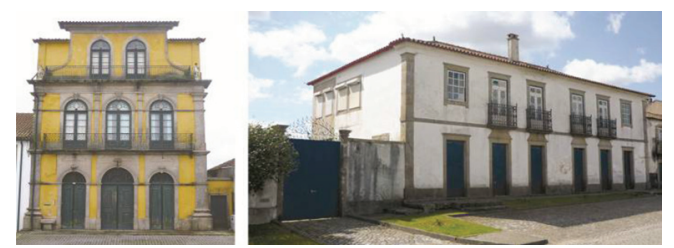

Figure 9. Examples of "brasileiro" and bourgeois street houses. (Credits: C.E. Barroso et al.).

The dwelling's organization was more complex, due to a larger number of compartments that included new functions like independent service areas, toilets, or the housemaid's bedroom. Services and commercial spaces at ground floor were frequent. These houses were frequently separated from the agricultural complex by an intermediated and more ceremonial courtyard, and agricultural premises were located in outbuildings on the external complex. 


\section{MATERIALS AND CONSTRUCTION TECHNIQUES}

\subsection{Local construction materials}

Local materials predominated in local construction and were extracted, prepared and applied by owners and the community. Master builders were only called to build complex structures, or to improved the quality buildings (Barroso, 2012).

As seen in Figure 10, due to its superficial or low depth availability, schist was the main structural masonry material. From metamorphic to sedimentary, from hard to claylike rocks (Costa, 2008), existing schist presents a great mineralogical and color diversity, originating different masonry performances.

Due to the study area's clay soil, different kinds of sands, clays and kaolin were available, allowing the frequent use of mortars and plasters, and the large-scale production of handcraft roof tiles and bricks.

Soil was also used for filling and laying masonry in low quality division walls. Wood was provided by a large area of forest, largely composed of pine trees (Pinus pinaster), oak trees (Quercos robur) and chestnut trees (Castanea sativa) (Cunha, 1932). Granites used to reinforce schist masonries, lime, gypsum, metals and glass, were all taken from outside (Barroso, 2012).

\subsection{Construction techniques}

The following constructive description is based on the typical block farmhouse (Fig. 4) and it is representative of most common construction techniques used in the studied buildings. As seen in Figure 11, these buildings were structurally composed of external two-floor height schist masonries, forming a "structural box", interlinked to each other, to ground floor partition masonry walls, and to horizontal structural timber elements of pavements and roofs (Barroso, 2012).

Structural masonry walls were composed by shallow foundations of $0.3 \mathrm{~m}$ deep, sometimes $0.1 \mathrm{~m}$ wider to each side of the wall, double masonry leaves enclosing a rubble internal core, and in more elaborated buildings, a granite or mortar cornice. As seen in Figure 12, wall's leaves were constituted of mortar bounded regular or irregular masonry, laid out in layers with larger masonry units placed at the lower part, and using small schist units as leveling wedges.

In order to increase walls' cohesion, units with more irregular faces were placed in the inner side of the wall, as opposed to external leaves, which were connected either by transversal stones, or attached to the core by deeply penetrating masonry units.
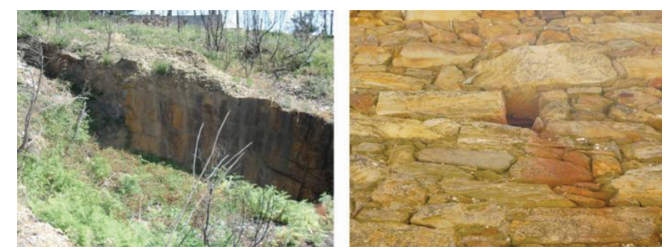

Figure 10. Example of abandoned schist quarry. Example of ochre, red and brown schist masonry. (Credits: C.E. Barroso et al.).

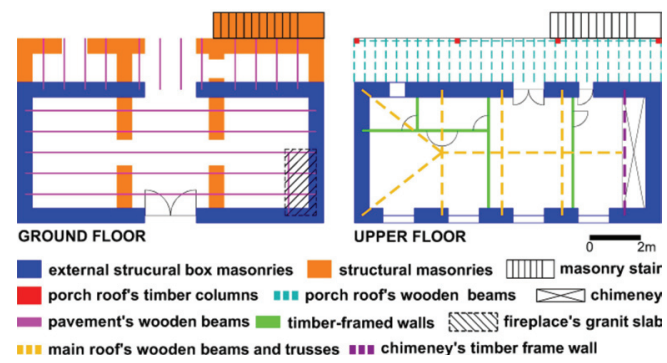

Figure 11. Example of block farmhouse structural schemes. (Credits: C.E. Barroso et al.).
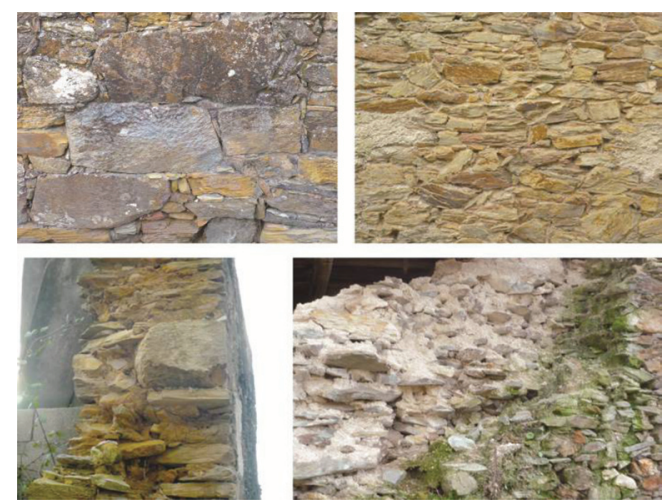

Figure 12. Examples of regular and irregular masonry. Examples of masonry's section and core. (Credits: C.E. Barroso et al.).

Average masonry walls' sections were of approximately $0.6 \mathrm{~m}$, reaching $0.8 \mathrm{~m}$ in over two-floor walls, decreasing $0.1 \mathrm{~m}$ at ground-floor level, and providing support to pavement's wooden beams. Thick sections and high mass gave these structural masonry walls stability, high thermal inertia and protection against climatic agents and moister. The high number of internal voids, schist low adhesion to mortars, due to its smooth surface and lamellar breakdown, representing some structural danger, particularly high in face of seismic actions (Roque, 2002). 
To minimize risks, connections between perpendicular walls were reinforced with bondestones, as seen in Figure 13, in granite on corners. Fragilities introduced by openings in masonry walls' structural continuity were resolved by reinforcements in granite or schist curbs and by constructing relieving arches (Appleton, 2011).

Horizontal structural timber elements were connected by embedment into walls, to a depth of $2 / 3$ of section (Teixeira, 2004). As seen in Figure 14, pavements were built whit wooden beams, covering an average of $6 \mathrm{~m}$ span, embedded in ground floor masonry walls and reinforced with wooden billets.

These were placed transversally between beams, and allowed better support for upper floor light timber frame walls and openings for stairs.

To allow the installation of the fireplace's granite slab $(0.2 \mathrm{~m} \times 1 \mathrm{~m} \times 2 \mathrm{~m})$ and oven, some extra beams were added to the pavement. The floorboards were applied directly over the beams, or over the battens. As seen in Figure 15, wooden roofs were structurally composed of trusses that supported ridges and purlins, and were embedded into the masonry walls. Rafters were placed over the purlins and were either embedded into the masonry walls or connected to the wooden beams. Battens were attached over the rafters and supported the tiles.

Due to the low resistance and less water tightness of the handcraft tiles, roofs were very ventilated and permeable, with slopes of around 20\%, not allowing attics and requiring constant maintenance. Single pitched roofs were built in simplified buildings, double pitched roofs in smaller buildings, and triple or more pitched roofs in larger buildings.

Existing ceilings were built in timber frame and in masseira style in higher quality buildings. In the mid-19th century, gypsum plaster ceilings became common. Wooden-paneled walls or light timber frame, covered with painted smooth gypsum plaster, were used for upper floor partitioning.

External and internal ground floor walls, not included in agricultural premises, were covered with lime painted plaster. Ground floor pavements were in compacted soil and external stairs were built in a compact schist masonry structure that supported the granite stone worked steps $(0.2 \mathrm{~m} \times 0.3 \mathrm{~m} \times 1.2 \mathrm{~m})$ and landings.

\section{CONCLUSIONS}

The study presented above, constitutes a demonstration of the intimate relation between vernacular construction, territory resources and human needs.
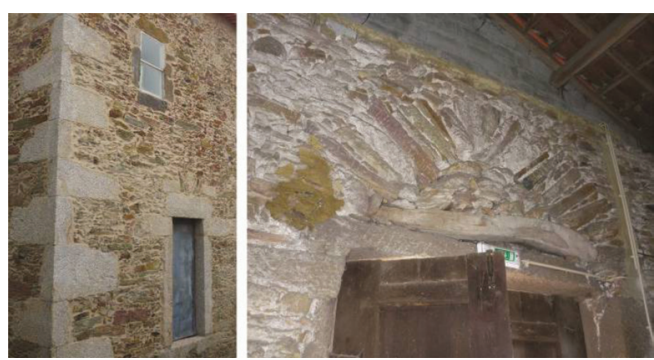

Figure 13. Examples of reinforced masonry walls with stoned worked granite and schist. Example of relieving arch. (Credits: C.E. Barroso et al.).
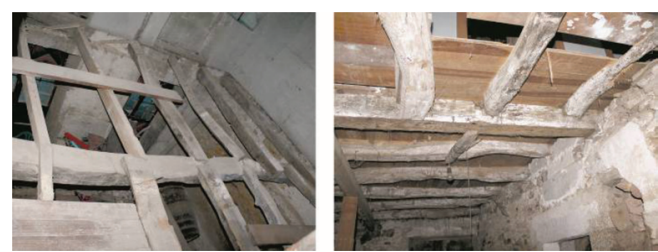

Figure 14. Example of a structural timber pavement. (Credits: C.E. Barroso et al.).
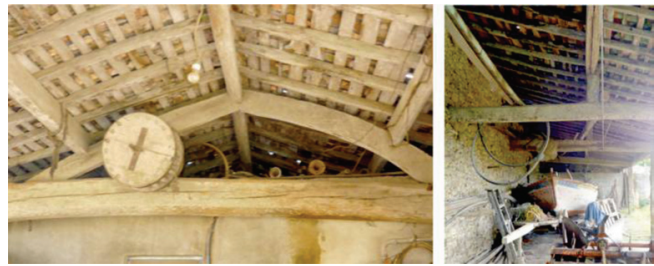

Figure 15. Examples of double and single pitched roofs. (Credits: C.E. Barroso et al.).

Based in these principles and sharing the same construction materials and techniques, the vernacular constructions studied show high morfo-typological diversity and capability to adapt to different circumstances, demonstrating a remarkable resistance to time and to life style changes. Basic human needs and economical activities, in particular the agricultural way of life, represented a key role in the development and evolution of the studied local morfo-typologies.

The widespread use of schist as structural masonry material for all kinds of buildings and infrastructure, led to construction techniques and solutions' adaptation to its natural capabilities, demonstrating its potential as construction resource. By the observations perform in the field- 
work study, it is notorious the high state of damage and loss of character, to which this heritage has been exposed. Lack of proper maintenance, damaging human interventions and property speculation, continues to threaten the still existent heritage. In the same context, vernacular heritage's identification with past poverty constitutes a great obstacle to its protection.

Attending to the information collected and presented in this paper, a significant part of the necessary conditions for sustainable an adapted to today's comfort rehabilitation of this heritage are already present and constitute the most promising way to its preservation and protection for future generations to come.

\section{ACKNOWLEDGEMENTS}

The first author wishes to express his gratitude to the Portuguese Science and Technology Foundation for the scholarship granted (SFRH/BD/ 86704/2012).

\section{REFERENCES}

Appleton, J.A. da S. (2011). Reabilitação de edificios antigos: patologias e tecnologias de intervenção (p. 716). Amadora: Edições Orion.

Araújo, A.V. de. (2001). Barqueiros retalhos da sua história (1 ${ }^{\mathrm{a}}$ ed.). Barcelos: Companhia Editora do Minho S.A.

Barroso, C.E. (2012). A construção vernacular em xisto entre o Cávado e o Ave-o caso de Barqueiros. Univer- sidade do Minho. Retrieved from http://www.sdum. uminho.pt/

Bastos, E.A. Lima; Barros, E. de. (1943). Inquérito à Habitação Rural. (1 ${ }^{a}$ ed., Vol. I, p. 445). Lisboa: Universidade Técnica de Lisboa.

Costa, J.B. (2008). Estudo e classificação das rochas por exame macroscópico $\left(11^{\text {a }}\right.$ ed., p. 196). Lisboa: Fundação Calouste Gulbenkien-Serviço de Educação e Bolsas.

Cunha, F. de M. (1932). NotasEtnográficas SobreBarcelos. (Instituto de Antropologia da Universidade do Porto, Ed.)Porto, Imprensa Portuguesa (1ºd.). Porto: Imprensa Nacional.

Fonseca, T. da (Associação de A. de P. (1987). O concelho de Barcelos aquém e além Cávado (Vol. II). Barcelos: Santa Casa da Misericórdia de Barcelos e CMB.

Monteiro, M. (2000). 1.Marcas arquitectónicas do "Brasileiro" na paisagem do minho. O Brasileiro de Torna Viagem (pp. 1-21). Lisboa: Comissão Nacional para as Comemorações dos Descobrimentos Portugueses.

Oliveira, E.V. de, \& Galhano, F. (1992). Arquitectura Tradicional Portuguesa (4a ed., p. 374). Lisboa: Publicações Dom Quixote.

Ribeiro, O. (1945). Portugal, o Mediterrâneo e o Atlântico. Coimbra, Editora Limitada (p. 245). Coimbra: Coimbra Editora. Retrieved from http://purl.pt/421

Roque, J. (2002). Reabilitação estrutural de paredes antigas de alvenaria. Universidade do Minho. Retrieved from http://bibliotecadigital.ipb.pt/handle/10198/1724

Teixeira, J.J.L. (FAUP). (2004). Descrição do sistema construtivo da casa burguesa do Porto entre os séculos XVII e XIX. Contributo para uma história da construção arquitectónica em Portugal. Universidade do Porto. 